UDC 621. 397.132: 621.391.837: 612.84: 535.6

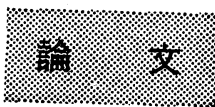

\title{
色度ノイズの視覚特性とカラーテレビ系 への応用
}

\author{
NHK 総合技術研究所藤尾孝 \\ NHK放送科学基礎研究所斎藤秀昭
}

カラーテレビのノイズは画面上輝度と色度のノイズになってあらわれるが，色度ノイズはその性質 や取扱い方法が明確でない，本論文は色度ノイズの体系化を目的に，カラーテレビ系の色度ノイズを 理論的に考察し試験して, 色度ノイズの表現法, さらにてれに対する等歩度色度座標を提案して, 広 く一般的な色度ノイズの取扱い方について検討考察した結果について述べる.

\section{1. ま え がき}

カラーテレビのノイズは, 画像を構成する $R, G, B$ 信 号のノイズによって定まり，画面上では一般に輝度ノイ ズと色度ノイズになってあらわれる.人の目は, 乙の輝 度ノイズの感じ方之, 色度ノイズの感じ方に差異がある ので, カラー画像のノイズを取り扱う場合は, ての両者 を分汀て考える必要がある. このうち輝度ノイズは従来 の白黒テレビにおけるノイズの性質や特性がそのまま適 用される種類のあのであるが, 色度ノイズに関してはこ れの性質や，取り扱い方がまだ明確にされていない現状 汇ある。

現在，わが国の標準方式である NTSC 信号では， イズが混入してから，カラー画像を再生するまでの系が 線形系の之き, 色チャネルのノイズはすべて輝度誤差の 伴わない色度ノイズとなってあらわれる，そして色度ノ

\section{筆 者 紹 介}

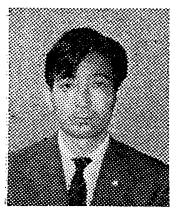

藤尾 势 孝 昭和 25 年, 兵庫工專電気科卒業. $\mathrm{NHK}$ 福井放送局技術部を経て, 昭和 29 年, 技術研究所テレ ビ研究部に勤務，カラーテレビ方式扰よびテレビ受像 方式の研究任従事. 正会員.

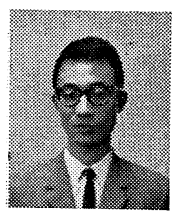

斉藤秀昭 昭和 37 年, 東北大学工学部通信工学科 卒業. 同年, NHK 飞就職, 昭和 40 年, NHK 技研に 転勤, 故送科学基碟研究所所属. 現在, 主として生体 の視觉機構に関する生理学的な研究に従事している.

"Visual Characteristics of Chrominance Noise and its Application for Television System" by Takashi Fujio (NHK Technical Research Laboratories, Tokyo) and Hideaki Saito (NHK Broadcasting Sciense Research Laboratory, Tokyo) テレビジョン画質研究委員会 (昭40.7) およびテレビジョン色彩研究委員会 (昭 40.11$)$ 発表.
イズの影響は一般に輝度ノイズの影響に対して低く，そ の差が数 $\mathrm{dB}$ あるといわれている(1) . しかし，乙の実 験は特定の色ラスターにお汀る特殊な色度ノイズについ ての屯ので，乙れを広く，一般のカラ一画像に適用する ことはできない

このような時点において，色度ノイズの体系化を目的 に，カラーテレビ系の色度、イズを理論的に考察し，視 覚試験して, 広く非線形動作を含んだ一般的な場合にあ 適用しうるよう検討を行なったので，その結果について 報告する。

\section{2. カラー信号の画面ノイズ2)33}

受像管螢光体の三原色発光量 $R, G, B$ がある瞬間, ノイズによって $\Delta R(t), \Delta G(t), \Delta B(t)$ だけ誤差を生じ たとき，画面にあらわれる輝度ノイズ $\Delta Y$ ，および色度 ノイズ $\Delta x, \Delta y$ は次式

$$
\left(\begin{array}{l}
\Delta Y \\
\Delta x \\
\Delta y
\end{array}\right)=\left(\begin{array}{lll}
\partial Y / \partial R & \partial Y / \partial G & \partial Y / \partial B \\
\partial x / \partial R & \partial x / \partial G & \partial x / \partial B \\
\partial y / \partial R & \partial y / \partial G & \partial y / \partial B
\end{array}\right)\left(\begin{array}{l}
\Delta R(t) \\
\Delta G(t) \\
\Delta B(t)
\end{array}\right)
$$

で与えられる.

$R, G, B$ 三原色を NTSC 三原色飞とり, 基礎刺戟 をC 光源白色に選んだとき，(1)式は

$$
\begin{aligned}
\left(\begin{array}{c}
\eta \Delta Y \\
\Delta x \\
\Delta y
\end{array}\right)=\eta\left(\begin{array}{cc}
0.299 & 0.587 \\
0.344 G+0.687 B, & -0.344 R+0.083 B, \\
-0.285 G+0.325 B, & 0.285 R+0.746 B, \\
0.114 \\
-0.687 R-0.083 G \\
-0.325 R-0.746 G
\end{array}\right)\left(\begin{array}{l}
\Delta R(t) \\
\Delta G(t) \\
\Delta B(t)
\end{array}\right) \\
\text { ただし, } \eta=(0.906 R+0.827 G+1.432 B)^{-2}
\end{aligned}
$$
となる。 


\section{1 色チャネルノイズによる画面ノイズ(線形系の場} 合）

カラーテレビ系が線形で, 色チャネル用 $R, G, B$ 信 号に $n_{R}, n_{G}, n_{B}$ で示されるノイズが加わったとき（た 之えば分離輝度カメラ系) 画面上のノイズを考える。乙 の場合，受像管励振信号はおのおの

$$
\left.\begin{array}{l}
E_{r}+n_{R-Y}=E_{r}+0.701 n_{R}-0.587 n_{G}-0.114 n_{B} \\
E_{g}+n_{G^{-}}=E_{g}-0.299 n_{R}+0.413 n_{G}-0.114 n_{B} \\
E_{b}+n_{B^{-}-}=E_{b}-0.299 n_{R}-0.587 n_{G}+0.886 n_{B}
\end{array}\right\}
$$

となる(図 1 (a) 参照).

受像管の励振電圧に対する発光出力の変換特性を直線 的とすると，(3)式の信号值が各光出力に対応するので 輝度ノイズ $\Delta Y$ は

$$
\Delta Y=\left(0.299 n_{R-Y}+0.587 n_{G-Y}+0.114 n_{B-Y}\right)=0
$$

之なり,画面には( 2 式の $\Delta R(t), \Delta G(t), \Delta B(t)$ 飞 $n_{R-Y}$, $n_{G-Y}$ および $n_{B-Y}$ を代入した色度ノイズのみがあらわれ る.

\section{2 色チャネルノイズによる画面ノイズ(非線形系の} 場合)

カラーテレビにおける非直線形は受像管の励振電圧対 発光出力の変換特性によって代表され, 乙の変換特性は 受像管動作点をビーム電流のカットオフ点におくときー 般飞

$$
L=k E^{\gamma}
$$

ただし， $E:$ 動作点より測った信号電圧

$\gamma$ : 受像管の動作状態により定まる定数 約 2.0

$k$ : 定数

であらわすととができる。

前項の場合之同様, 色チャネル用 $R, G, B$ 信号飞 $n_{R}, n_{G}, n_{B}$ が加わり，(5)式であらわされる特性の受像 管で画像を再生した場合を考える.

第 2 次微小項による誤差を無視して考えるとき, 輝度 ノイズ $\Delta Y$ は

$$
\begin{aligned}
\Delta Y= & \left(0.299 \gamma E_{\tau}^{\gamma-1} n_{R-Y}+0.587 \gamma E_{g}^{\gamma-1} n_{G-Y}\right. \\
& \left.+0.114 \gamma E_{b}^{\gamma-1} n_{B-Y}\right)
\end{aligned}
$$

よなる，またての場合の色度ノイズは

$$
\begin{aligned}
& \Delta x_{m}= {\left[\left(0.344 E_{g}^{\gamma}+0.687 E_{b}^{\gamma}\right) E_{r}^{\gamma-1} \alpha_{1 m}\right.} \\
&+\left(-0.344 E_{r}^{\gamma}+0.083 E_{b}^{\gamma}\right) E_{g}^{\gamma-1} \alpha_{2 m} \\
&\left.+\left(-0.687 E_{r}^{\gamma}-0.083 E_{g}^{\gamma}\right) E_{b}^{\gamma-1} \alpha_{3 m}\right] \gamma n_{m} / J \\
& \Delta y_{m}= {\left[\left(-0.285 E_{g}^{\gamma}+0.325 E_{b}^{\gamma}\right) E_{r}^{\gamma-1} \alpha_{1 m}\right.} \\
&+\left(0.285 E_{r}^{\gamma}+0.746 E_{b}^{\gamma}\right) E_{g}^{\gamma-1} \alpha_{2 m} \\
&\left.+\left(-0.687 E_{r}^{\gamma}-0.083 E_{g}^{\gamma}\right) E_{b}^{\gamma-1} \alpha_{3 m}\right] \gamma n_{m} / J \\
& m=R, G, B \\
& \text { ただし, } J=\left(0.906 E_{r}^{\gamma}+0.827 E_{g}^{\gamma}+1.432 E_{b}^{\gamma}\right)^{2}
\end{aligned}
$$

\section{色度ノイズの視覚特性とカラーテレビ系への応用】論 文}

$$
\left(\begin{array}{lll}
\alpha_{1 R} & \alpha_{1 G} & \alpha_{1 B} \\
\alpha_{2 R} & \alpha_{2 G} & \alpha_{2 B} \\
\alpha_{3 R} & \alpha_{3 G} & \alpha_{3 B}
\end{array}\right)=\left(\begin{array}{rrr}
0.701 & -0.587 & -0.114 \\
-0.299 & 0.413 & -0.114 \\
-0.299 & -0.587 & 0.886
\end{array}\right)
$$

で与えられる。

\section{3. カラー受像管上における色度 ノイズの再現 ${ }^{233}$}

\section{1 白色上の色度ノイズ}

カラー受像管に加える信号が受像管の非線形特性を補 償するように補正されていないと，色チャネルのノイズ は一般に色度ノイズの他に輝度ノイズも伴う。しかし， 無彩色上では $E_{r}=E_{g}=E_{o}$ のため $(6)$ 式で明らかなよ うに色度ノイズのみとなり, 白色画面上では線形系の $\gamma$ 倍の色度ノイズがあらわれる（図１(a)）。

\section{2 補色上の色度ノィズ}

補色は受像管変換特性の動作範囲を同じくし, 刺戟値 の等しい 2 色の混合によって得られるむので, 非線形の 動作に対しても輝度ノイズ成分を消し去ることができ， 受像管上に色度ノイズのみを再現することができる．

たとえば，黄色(青の補色)画面上に色度ノイズをディ スプレーするには R, G 各電子銃に $E_{e}+n_{r}, E_{e}+n_{g}$ な る信号を加え，G電子銃に加えるノイズ成分 $n_{g}$ を

$$
n_{g}=-\frac{0.299}{0.587} n_{r}=-0.509 n_{r}
$$

飞選ぶ.

そうすると $(6)$ 式より輝度ノイズ成分 $\Delta Y_{y}$ は

$$
\Delta Y_{y}=0.299 \gamma E_{e}^{\gamma-1} n_{r}+0.587 \gamma E_{e}^{\gamma-1} n_{g}=0
$$

となり，画面には CIE 表示で

$$
\left.\begin{array}{l}
\Delta x=\frac{0.344 \times 1.509 \gamma n_{r}}{1.733^{2}} \\
\Delta y=\frac{-0.285 \times 1.509 \gamma n_{r}}{1.733^{2}}
\end{array}\right\}
$$

であらわされる色度ノイズのみがあらわれる(図1(b))。

\section{3 原色上の色度ノイズ}

以上はカラーテレビ系が非線形動作をしている場合の 色度ノイズについて考えたが, 色チャネルにノイズを加 え, 乙れを含んだ復調 $R, G, B$ 信号を, 受像管の非線 形変換特性を補償するようガンマ補正して受像管に加え ると，任意の色度をすつ画面上に輝度ノイズを伴わない 色度ノイズを再現することができる。

受像管のカットオフやガンマという非線形特性のため 一般にカラーテレビに执いては，原色上に輝度ノイズを 伴わないで色度ノイズのみが存在するというととはあり 得ない。しかし上記のように，復調信号に受像管の非線 形特性に対するガンマ補正を行なえば，原色に近い画像 上に色度ノイズのみを再現することができる。

(19) 819 


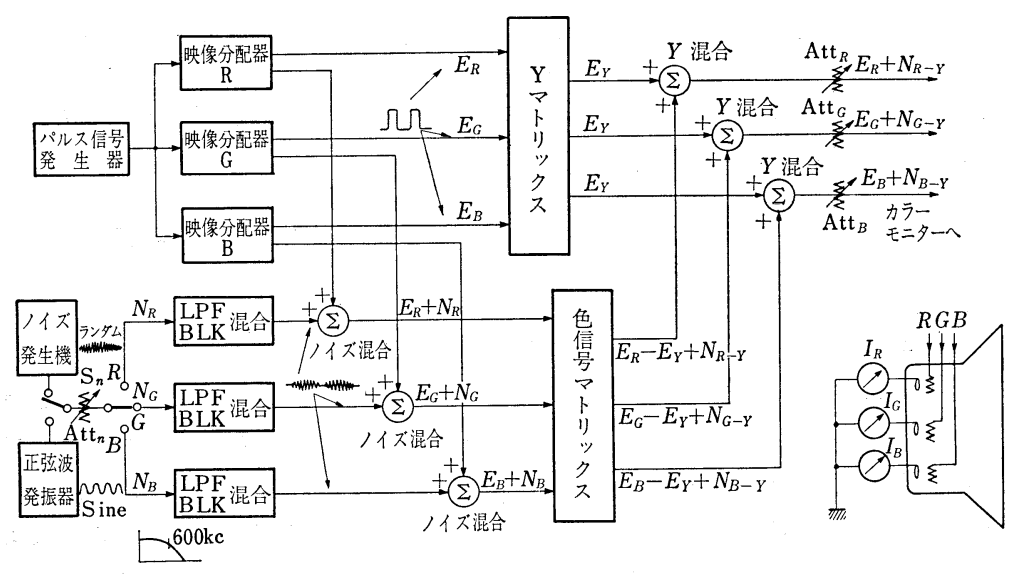

図 1 (a) 白色画面上色度ノイズディスプレー回路系統図 Circuit diagram for subjective assessment of chrominance noise on the achromatic color backgrounds.

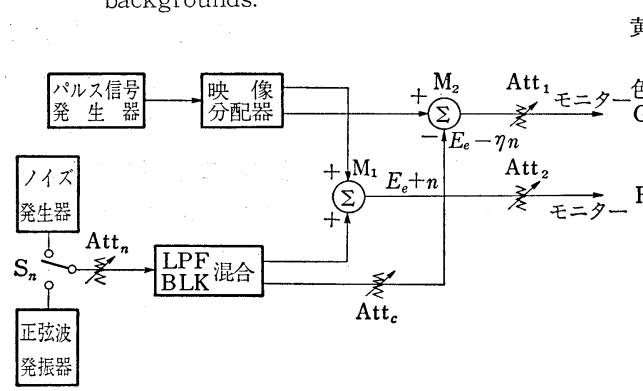

図 1(b) 補色上の色度ノイズ試験系統図 Circuit biagram for subjective assessment of chrominance noise on the complemental color backgrounds.

\section{4. 色度ノイズの検知限評価 ${ }^{3)-5) 14)}$}

\section{1 評価の条件}

(a) 受像管

21 CYP 22

表 1 營光体色度

Chromaticity co-ordinate of red, green and blue phosphor primaries.

\begin{tabular}{c|c|c|c}
\hline \hline 溃 光 & $\boldsymbol{x}$ & $\boldsymbol{y}$ & $\boldsymbol{z}$ \\
\hline 赤 & 0.674 & 0.326 & 0.000 \\
緑 & 0.218 & 0.712 & 0.070 \\
青 & 0.146 & 0.052 & 0.802 \\
\hline
\end{tabular}

(b) 画面輝度之画面の大きさ

ビーム, スポットの広がり, 受像管高压の変動, さら にこれに伴う色の重㸚合せのずれなどを考慮して

白色画面輝度 $10 \mathrm{fL}$ 以下

画面サイズ $\quad 110 \mathrm{~mm} \times 80 \mathrm{~mm}$

(c) ノイズ源

$600 \mathrm{kc}$ 帯域の白色ノイズと, 周波数が約 $500 \mathrm{kc}$ で移 動速度が $40 \mathrm{~mm} / \mathrm{sec}$ の正弦波ノイズ. (d) 観視条件

周囲光 暗室

観視距離 $800 \mathrm{~mm}$

(e) 画像

ソリッド・ラスター

色度 白色, 三原色補色, 館 和度約 $90 \%$ の三原色.

\section{2 色度ノイズの検知限評価 とその結果}

以上の条件を定め, テレビ技術 者 9 名により色度ノイズの検知限 を評価試験した。との結果を見る と, 色度ノイズの絶対評価にはか なりの個人差がある。これの原因 としては，色度ノイズに対する眼 の感度差によるむのと，いまひと つ，どの点を検知限にするかとい

表 2 白色画面上の色度ノイズ検知限

Perception limit of chrominance noise on the achromatic color backgrounds. (単位 $\mathrm{dB}$ )

\begin{tabular}{|c|c|c|c|c|c|c|}
\hline , 12 & \multicolumn{3}{|c|}{ 正弦波ノイス } & \multicolumn{3}{|c|}{ 白色, } \\
\hline 检知限 S & $N_{R}$ & $N_{G}$ & $N_{B}$ & $N_{R}$ & $N_{G}$ & $N_{B}$ \\
\hline 色度ノイズ検知限 & 43 & 41 & 41 & 32 & 32 & 31 \\
\hline 標 準 偏 差 & 1.1 & 1.5 & 1.6 & 1.6 & 1.4 & \\
\hline 計＜wide>算 & 41 & 41 & 41 & 31 & 31 & 31 \\
\hline
\end{tabular}

表 3 補色画面上の色度ノイズ検知限

Perception limit of chrominance noise on the complementary color backgrounds. (単位 $\mathrm{dB}$ )

\begin{tabular}{|c|c|c|c|c|c|c|}
\hline ノイズ & \multicolumn{3}{|c|}{ 正弦波ノイズ } & \multicolumn{3}{|c|}{ 白色ノ1 } \\
\hline 検知限 SN 比 & 黄 色 & シアン & マゼンタ & 黄 色 & シアン & マゼンタ \\
\hline 色度ノイズ検知限 & 48 & 44 & 50 & 38 & 34 & 40 \\
\hline 標 準 偏 差 & 0.7 & 1.6 & 0.7 & 0.6 & 1.7 & 1.1 \\
\hline 算 & 47.5 & 44.6 & 50.0 & 37.5 & 34.6 & 40.0 \\
\hline 輝度ノイズ検知限 & 60 & 60 & 60 & 51 & 51 & 51 \\
\hline
\end{tabular}

表 4 原色画面上の正弦波色度ノイズの検知限 Perception limit of chrominance sine wave noise on the primary color backgrounds. (単位 $\mathrm{dB}$ )

\begin{tabular}{|c|c|c|c|c|c|c|c|c|c|}
\hline 背景色 & 赤 & & 色 & 緑 & & 色 & 青 & & 色 \\
\hline 回限 SN 比 & $N_{R}$ & $N_{G}$ & $N_{B}$ & $N_{R}$ & $N_{G}$ & $N_{B}$ & $N_{R}$ & $N_{G}$ & $N_{B}$ \\
\hline イズ検知限 & 44 & 44.5 & 43.5 & 38.5 & 38 & 39 & 42 & 42.5 & 42 \\
\hline 標 準 偏 差 & 1.2 & & & & 0.8 & & & & 1.1 \\
\hline 計 算 値 & 44.7 & 44.7 & 44.7 & 39 & 39 & 39 & 43 & 43 & 43 \\
\hline
\end{tabular}

表 5 原色画面上白色色度ノイズの検知限

Perception limit of chrominace white noise on the primary color backgrounds. (単位 $d B$ )

\begin{tabular}{|c|c|c|c|c|c|c|c|c|c|}
\hline 背景色 & 赤 & & 色 & 緑 & & 色 & 青 & & 色 \\
\hline SN 比 & $N_{R}$ & $N_{G}$ & $N_{B}$ & $N_{R}$ & $N_{G}$ & $N_{B}$ & $N_{R}$ & $N_{G}$ & $N_{B}$ \\
\hline 色度ノイズ検知限 & 34 & 34.5 & 33.5 & 28.5 & 28 & 29 & 32 & 32.5 & 32 \\
\hline 計 算 值 & 34.6 & 34.6 & 34.6 & 28.9 & 28.9 & 28.9 & 32.9 & 32.9 & 32.9 \\
\hline
\end{tabular}




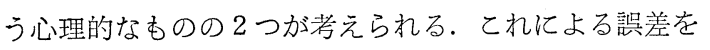
できるだけ少なくするため, 実際は, 各人が輝度ノイズ と色度ノイズの両者の検知限を評価し，てれらの間の偏 差が各人固有のあのであるとするような方法でデータを 整理した. とのような方法をとるととにより評価值の標 準偏差が平均して約 $1 \mathrm{~dB}$ 改善できた.

表 2 ～表 5 は評価試験結果を示したあのである.

\section{3 多重色度ノイズの妨害度}

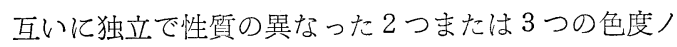
イズが共存したときどのようになるかが問題となる。乙 れについては, 白色画面上飞 $n_{R}, n_{G}, n_{B}$ のうちの $2 つ ま$ たは 3 つが共存する場合の検知限を, 抒のおのが単独に あるときの検知限と比較して試験した.この結果, これら の色度ノイズは電力加算的に取り扱ってよいといえる.

\section{5. 視覚特性を考慮した色度ノイズの 定義とその表現法 ${ }^{3)-5) 12) ~}$}

色于ャネル用 $R, G, B$ 信号に無相関ノイズ $n_{R}, n_{G}, n_{B}$ が混入した系を考えるとき, カラー画面上では(2)また 林(7)式で示さ机るような 3 つの独立した色度ノイズが 共存する.

しかし，乙の色度ノイズでは背景色に依存し，たとえ ば $n_{R}$ を例にとって考えると, 白色上では“赤↔シアン” に変わる色度ノイズをあらわしているが，赤色上では “赤↔白色”にその色度が変わるようなノイズであある.

そして，乙の場合のノイズは受像管動作が線形のとき (3)式であらわされ, たとえば, 無彩色上（理解しやす 心ため) $n_{G}=n_{B}=0$ のときについて考えると，画面上で は図 2 のように $n_{R}>0$ のときには $\left(A-0.299 n_{R}\right)$ の無色 彩(背景色) 上で $n_{R}$ 単位の刺激量でもって赤色変わる 色ノイズであり， $n_{R}<00$ ときには $\left(A+0.299 n_{R}\right)$ の無 彩色上, 単位 $n_{R}$ の刺激量でもってシアンに変わる色ノ イズであある.ゆえに $0.299 n_{R} \ll A$ の状態では, 画 面上に $n_{R}$ 単位の色度ノイズがあらわれたと考えうる。 $n_{G}, n_{B}$ に対してあ同様で, その色度ノイズの刺激量は $n_{G}, n_{B}$ が単位の色度ノイズがあらわれる.

$R$ 出力波形 $\quad G$ 出力波形 $\quad B$ 出力波形

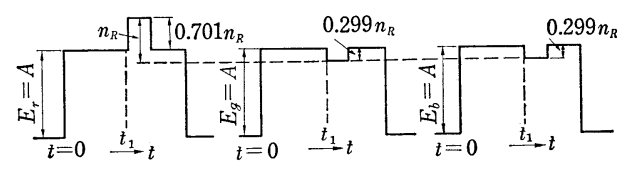

図 2 無彩色上 $N_{R}$ 亿よる三原色刺激量 Tristimulus values of $n_{R}$ on the achromatic color background.
表 6 色度ノイズの妨害量

Interference of chrominance noise.

\begin{tabular}{|c|c|c|c|c|}
\hline 背景色 & ノ 1 ズ & 妨 & 害 & 備 \\
\hline 白 & $\begin{array}{l}n_{R} \\
n_{G} \\
n_{B}\end{array}$ & {$\left[\gamma n_{m} /\right.$} & $b+c) \beth_{m=R, G, B}$ & 非線形動作 \\
\hline 黄 色 & 赤に $n_{y}$ & $1.509 \gamma$ & $(a+b)$ & 非線形動作 \\
\hline シアン & 青に $n_{c}$ & $1.194 \gamma$ & $(b+c)$ & 非線形動作 \\
\hline マゼンタ & 青に $n_{m}$ & $1.381 \gamma$ & $(a+c)$ & 非線形動作 \\
\hline 赤 & $n_{R}, n_{G}, n_{B}$ & $\left(n_{m} /[c\right.$ & $r(b+c)])_{m=R, G, B}$ & 線形動作 \\
\hline 緑 & $n_{R}, n_{G}, n_{B}$ & $\left(n_{m} /[b\right.$ & $g(a+c)])_{m=R, G, B}$ & 線形動作 \\
\hline 青 & $n_{R}, n_{G}, n_{B}$ & $\left(n_{m} /[c\right.$ & $b(a+b)])_{m=R, G, B}$ & 線形動作 \\
\hline
\end{tabular}

一方，白色画像は三原色を同じ量混合して得たもので あるため，前記白色上の $N_{R}, N_{G}, N_{B}$ 汒よってあらわ される 3 種類の色度ノイズについては, その妨害量がご く似かよったものであり，一応同じ程度で妨害するあの 之推察される，すなわち無彩色上では， $N_{R}$ は赫↔シア ン， $N_{B}$ は青↔黄色に色度が変わるノイズではあるがそ の相対量が等しければ，妨害の程度も同じと考えうる. それゆえ， $N_{R}, N_{G}, N_{B}$ のノイズ量のみに着目し，てれ による妨害の度合が背景色に依存しているあのと考え, 三原色の発光出力が $R, G, B$ なる画面上の色度ノイズ $N$ による妨害量 $D$ を

$$
D=\frac{N}{(a R+b G+c B)}
$$

ただし，重み係数の和 $a+b+c=1$ とする.

と仮定すると, 白色, 補色, 原色上の色度ノイズの妨害 量は表 6 のようになる。

\section{1 色度ノイズに対する背景色の重み係数}

4.2 で試験した色度ノイズの評価值から，(10)式に仮 定した色度ノイズに対する背景色の重み係数を求めると 3 つの重み係数 $a, b, c$ は

$$
a \simeq 0.21, b \simeq 0.51, c \simeq 0.28
$$

となる. そして, 色度ノイズの妨害量の逆数を $K$ とす るとき, 正弦波色度ノイズの検知限に対する $K$ の值, および, 白色色度ノイズ(带域 $600 \mathrm{kc}$ )の検知限に対する $K$ の值, $K_{S}, K_{W}$ は平均的に

$$
K_{S}=50, K_{W}=15.5
$$

として取り扱うととができる.

すなわち，(10)式の $N, R, G, B$ をピーク白色飞対 する発光量で規準化し， $n, r, g, b$ であらわしたとき

$$
\frac{1}{n}=\frac{50}{0.21 r+0.51 g+0.28 b}
$$

が正弦波色度ノイズの検知限 SN 比をあらわし, $600 \mathrm{kc}$ 帯域の白色ノイズに対する色度ノイズの検知限 $\mathrm{SN}$ 比は

$$
\frac{1}{n}=\frac{15.5}{0.21 r+0.51 g+0.28 b}
$$

\footnotetext{
* $N_{m}$ はノイズの緦対刺激量をあらわす.
} 
で与えられる。

表 2 表 5 に示した色度ノイズ検知限の計算值は, (11)，(12)式を用いて求めたもので，乙の結果，(11)式 (12)式を用いて色度ノイズを数式的に取り扱えることが わかる。

\section{2 色度ノイズと信号の SN 比}

カラーテレビ系が線形として取り扱える場合は, 色チ ヤネルに混入したノイズはすべて色度ノイズのみとなっ てあらわれ，受像管の非線形補正回路の入力側で定義し た相対信号量およびノイズ量が三原色の相対発光量とな る.このため, (11), (12)式が直接, 信号の SN 比とし て取り扱える.すなわち $600 \mathrm{kc}$ 帯域の白色ノイズにつ いて考えるとき

$$
\frac{1}{n}=\frac{15.5}{0.21 E_{r}+0.51 E_{g}+0.28 E_{b}}
$$

ただし， $E_{r}, E_{g}, E_{b}$ は三原色信号をピーク白色に

対する信号電圧で規準化したもの.

であらわされる值は信号の色度ノイズの検知限 SN 比で ある.

表 7 は，系が直線的として取り扱える場合で，色信号 用 $\mathrm{R}, \mathrm{G}, \mathrm{B}$ カメラのノイズ電力が等しい状態を仮定し たとき，いろいろなカラー画面上の白色ノイズによる色

表 7 各背景色上の色度ノイズ検知限に対する カメラの $\mathrm{SN}$ 比

Required SNR to color camera out put signal for perception limit of chrominance noise on the various color backgrounds.

\begin{tabular}{|c|c|c|c|c|c|c|}
\hline \multirow{2}{*}{ 背 } & \multirow{2}{*}{ 景 } & \multirow{2}{*}{ 色 } & \multicolumn{3}{|c|}{$R, G, B$ 表示 } & \multirow{2}{*}{$\begin{array}{c}\text { 検知限に対する } \\
\text { カメラの } \\
\text { (dB) 比 }\end{array}$} \\
\hline & & & $\mathrm{R}$ & G & $\mathrm{B}$ & \\
\hline & 白 & & 1 & 1 & 1 & 29 \\
\hline & 黄 & & 1 & 1 & $\varepsilon$ & 31 \\
\hline シ & 了 & ン & $\varepsilon$ & 1 & 1 & 30 \\
\hline$\nabla$ & ゼ ン & 夕 & 1 & $\varepsilon$ & 1 & 34 \\
\hline & 赤 & & 1 & $\varepsilon$ & $\varepsilon$ & 39 \\
\hline & 緑 & & $\varepsilon$ & 1 & $\varepsilon$ & 34 \\
\hline & 青 & & $\varepsilon$ & $\varepsilon$ & 1 & 38 \\
\hline
\end{tabular}

(注) ノイズは $600 \mathrm{kc}$ 带域の白色ノイズ SN 此忙（信号のピーク値)/(ノイズの実效值) $\varepsilon=0.1$

表 8 各背景色に対する色度ノイズの SN 比 SNR of chrominance noise on the various color backgrounds.

\begin{tabular}{|c|c|c|c|c|c|c|}
\hline \multirow{2}{*}{ 背景色 } & \multicolumn{3}{|c|}{$\mathrm{R}, \mathrm{G}, \mathrm{B}$ 表示 } & \multirow{2}{*}{$\begin{array}{c}\text { 喥ノイズの } \\
\text { 等価 SN 比. } \\
\text { (dB) }\end{array}$} & \multirow{2}{*}{$\begin{array}{c}\text { 検知限 SN 此 } \\
\text { ○偏差 } \\
(\mathrm{dB})\end{array}$} & \multirow{2}{*}{ 備 考 } \\
\hline & $\mathrm{R}$ & G & B & & & \\
\hline 白 & 1 & 1 & 1 & 24 & 0 & 検知限 \\
\hline 黄 & 1 & 1 & $\varepsilon$ & 21 & -2.5 & 許容 \\
\hline シアン & $\varepsilon$ & 1 & 1 & 22 & -1.8 & 許容 \\
\hline マゼンタ & 1 & $\varepsilon$ & 1 & 19 & -5.3 & 許容 \\
\hline 赤 & 1 & $\varepsilon$ & $\varepsilon$ & 13 & -10.8 & \\
\hline 緑 & $\varepsilon$ & 1 & $\varepsilon$ & 19 & -5.0 & 許容 \\
\hline 青 & $\varepsilon$ & $\varepsilon$ & 1 & 15 & -9.1 & \\
\hline
\end{tabular}

（注）ノイズは $600 \mathrm{kc}$ 带域の白色ノイズ $\varepsilon=0.1$

$822(22)$
度ノイズが見えなくなるために必要なカメラの SN 比を 計算したものである.

\section{3 色度ノイズに対する等価 SN 比の定義}

(10)式に定義した妨害量の逆数，すなわち $K$

$$
K=\frac{\left(0.21 E_{r}+0.51 E_{g}+0.28 E_{b}\right)}{n}
$$

を色度ノイズの等価 $\mathrm{SN}$ 比と定義すると便利である。乙 のようにすると

$\begin{array}{ll}\text { 正弦波色度ノイズに対しては } & 34 \mathrm{~dB} \\ \text { 白色色度ノイズに対しては } & 24 \mathrm{~dB}\end{array}$
が色度ノイズの検知限に打的等価 SN 比となる。

表 8 は，白色画面上で色度ノイズが見えなくなるよう なノイズ $n$ が混入したとき，上の定義にしたがった各画 面上の色度ノイズ等価 $\mathrm{SN}$ 比がどのようになるかを計算 したあのである。

この表によれば， $n$ によってうける黄色上の妨害は， 検知限より $2.5 \mathrm{~dB}$ だけ大きい.

\section{4 多重化カラー信号に混入したノイズによる色度 ノイズの妨害量と等価 SN 比}

多重化カラー信号の色信号チャネルにノイズが混入し た場合を考える.ノイズスペクトルが色副搬送近傍にの み分布し，輝度チャネルに影響しないものとすると，

復調 $R$ 信号に混入するノイズは $1.14 n_{i}$

$$
\begin{array}{cccc}
\text { " } G \quad \text { " } & \text { " } & -0.581 n_{i}-0.394 n_{q} \\
\text { " } B & \text { " } & 2.03 n_{q}
\end{array}
$$

ただし， $n_{i}, n_{q}$ は， $n$ を混入するノイズ電圧と

するとき， $n$ を直交分解した各成分で $\bar{n}_{i}{ }^{2}=\bar{n}_{q}{ }^{2}$ $=\bar{n}^{2} / 2$ となる.

ゆえにこの場合は $1.72 n_{i}$ であらわされる色度ノイズ と $2.42 n_{q}$ であらわされる 2 つの独立な色度ノイズが画 面にあらわれ，乙れらが電力的に加算されたあので妨害 する. この結果, 各色画面上で $n$ による色度ノイズが見 えなくなる信号の SN 比は

$$
\frac{32.6}{\left(0.21 E_{r}+0.15 E_{g}+0.29 E_{b}\right)}
$$

で与えられ，また前の定義にしたがってあらわした各色 画面上に打忊る色度ノイズの等価 SN 比は

$$
\frac{\left(0.21 E_{r}+0.51 E_{g}+0.28 E_{b}\right)}{2.10 n}
$$

となる。

NTSC 信号は色信号を輝度信号よりも情報量が少ない 状態で伝送しているが，低域成分について考えたとき， 赤および青色差信号を輝度信号と等しい信号量で伝送す るようなう式では

$R$ 信号に混入するノイズは $n_{i}$

$$
\text { G信号に " }-0.509 n_{i}-0.194 n_{q}
$$


$B$ 信号に混入するノイズは $n_{q}$ で，妨害ノイズ量は $1.36 n$ となり, 現在のカラー方式 に比して色度ノイズの改善度は 2.10/1.36 =1.54 となっ て，3.8dB 改善されるととになる.

\section{6. 色度ノイズの色度図表示 ${ }^{3) 5311121}$}

\subsection{CIE 色度図上の表示}

正弦波ノイズおよび白色ノイズによる色度ノイズの検 知限 SN 比は，(11)拉よび(12)式であらわすことができ る. てのため各カラー画像につき(11)式および(12)式を 満足する $n$ が, おの打の $n_{R}, n_{G}, n_{B}$ である場合，(2) 式にしたがってその色度変化量孛求めると, CIE 色度図 上に色度ノイズの非検知範囲を描くことができる.

図３はこのような方法で(11)式であらわした色度ノイ ズによる非検知範囲を，10倍(長さの単位で)の大きさに 拡大して描いたあのである.すなわち，正弦波の実効値 であらわした色度ノイズが図 3 に示した楕円の $1 / 10$ の 範囲内にあれば，色度ノイズは検知されない。また，白 色ノイズによる色度ノイズの検知限 $\mathrm{SN}$ 比は正弦波によ るものより $10 \mathrm{~dB}$ 低いと見なしうるため, 白色ノイズの 実効值であらわした色度ノイズが図 3 に示した楕円の約 1/3 の範囲内にあれば，これによる色度ノイズは検知し ない.

また, Judd が感覚的に等しいと感ずる色度範囲を CIE 色度図上に描いて提案したものがあるが，図 3 はこれに よく類似している.

\section{2 色度ノイズに対する U C S 色文座標の誘導}

一般カラ一画像の伝送系は非線形補正を送像側で行な うため,ノイズによっては受像管の非線形動作の影響を 考慮しなければならず，色度ノイズも前述のように簡単 に取り扱えない場合が生ずる.

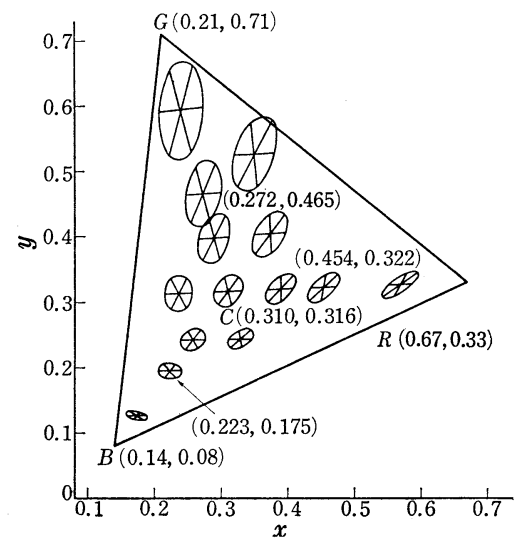

図 $3 \mathrm{CIE}$ 色度図上の色度ノイズ検知限 Perception limit of chrominance noise showed on the CIE chromaticity diagram.
色度ノイズの視覚特性とカラーテレビ系への応用】論 文

すなわち，色チャネルに混入したノイズも一部は輝度 ノイズに変換され, 実際のカラー画面上には，(7)式で 示されるような色度ノイズと, (6)式で示される輝度) イズとの両者が混じり合ってあらわれる.

てのうち輝度ノイズについては，信号電圧と受像管の 動作状態を与えれば，（6)式によって求めることができ これは他の輝度ノイズとの電力和であらわされるノイズ 量となって画面に輝度ノイズ妨害を与える.

一方, 色度ノイズはCIE系で表示すると(7)式で与え られるが, 図 2 からわかるように, CIE 色度図は眼の色 度ノイズに対して感ずる感覚的な色度差とは対応のない あのであるため，(7)式の值であって直接色度ノイズの 妨害度を求めることはできない。しかし, 色度ノイズの 妨害に対する等歩度色度座標を見出すととができれば， この種一般的な色度ノイズの妨害も計算により求めるこ とができる.

いま， 1 組の新しい三刺戟値 $U, V, W$ を想定し， これをCIE系の三刺戟值 $X, Y, Z$ によって次のように あらわせるあのとする。すなおち

$$
\left(\begin{array}{c}
U \\
V \\
W
\end{array}\right)=\left(a_{i k}\right)\left(\begin{array}{c}
X \\
Y \\
Z
\end{array}\right)=\left(\begin{array}{lll}
a_{11} & a_{12} & a_{13} \\
a_{21} & a_{22} & a_{23} \\
a_{31} & a_{32} & a_{33}
\end{array}\right)\left(\begin{array}{c}
X \\
Y \\
Z
\end{array}\right)
$$

とするとき, $U, V, W$ 系の色度 $u, v$ は

$$
\begin{aligned}
& u=\frac{\left(a_{11}-a_{13}\right) x+\left(a_{12}-a_{13}\right) y+a_{13}}{\left(\sum a_{n 1}-\sum a_{n 3}\right) x+\left(\sum a_{n 2}-\sum a_{n 3}\right) y+\sum a_{n 3}} \\
&=\frac{\left(a_{11}-a_{13}\right) x+\left(a_{12}-a_{13}\right) y+a_{13}}{\left(S_{X}-S_{Z}\right) x+\left(S_{Y}-S_{Z}\right) y+S_{Z}} \\
& v=\frac{\left(a_{21}-a_{23}\right) x+\left(a_{22}-a_{23}\right) y+a_{23}}{\left(\sum a_{n 1}-\sum a_{n 3}\right) x+\left(\sum a_{n 2}-\sum a_{n 3}\right) y+\sum a_{n 3}} \\
&=\frac{\left(a_{21}-a_{23}\right) x+\left(a_{22}-a_{23}\right) y+a_{23}}{\left(S_{X}-S_{Z}\right) x+\left(S_{Y}-S_{Z}\right) y+S_{Z}} \\
&\text { ただし, } \left.\quad \sum_{m=1,2,3} a_{n m}\right)=\sum_{n=1}^{3} a_{n m} \\
& \quad S_{X}=\sum_{n=1}^{3} a_{n 1}, \quad S_{Y}=\sum_{n=1}^{3} a_{n 2}, \quad S_{Z}=\sum_{n=1}^{\dot{2}} a_{n 3}
\end{aligned}
$$

であらわされる。

$$
\begin{aligned}
S_{Z}=\sum_{n=1}^{3} a_{n 3}=1 \text { に選ぶと(18)式は } \\
u=\frac{\left(a_{11}-a_{13}\right) x+\left(a_{12}-a_{13}\right) y+a_{13}}{\left(S_{X}-1\right) x+\left(S_{Y}-1\right) y+1} \\
=\frac{m_{1} x+m_{2} y+m_{3}}{m_{7} x+m_{8} y+1} \\
v=\frac{\left(a_{21}-a_{23}\right) x+\left(a_{22}-a_{23}\right) y+a_{23}}{\left(S_{X}-1\right) x+\left(S_{Y}-1\right) y+1} \\
=\frac{m_{4} x+m_{5} y+m_{6}}{m_{7} x+m_{8} y+1}
\end{aligned}
$$

となり，新しい三原色の選定において第一原色および第 
三原色 $(U),(W)$ を輝度 0 の平面におき, 刺戟值 $V$ を $Y$ に対応させ，かつ第三原色が $Z$ 軸上にあるように選ぶ と(19)式は

$$
\begin{aligned}
& u=\frac{S_{X} U_{X} x}{\left(S_{X}-1\right) x+\left(S_{Y}-1\right) y+1}=\frac{m_{1} x}{m_{7} x+m_{8} y+1} \\
& v=\frac{S_{Y} V_{Y} y}{\left(S_{X}-1\right) x+\left(S_{Y}-1\right) y+1}=\frac{m_{5} y}{m_{7} x+m_{8} y+1}
\end{aligned}
$$

となる・

一方，任意の色度画面上 $n_{R}, n_{G}, n_{B}$ に対する色度誤 差

$$
\begin{aligned}
\left(\begin{array}{c}
\Delta x_{m} \\
\Delta y_{m}
\end{array}\right)_{m=R, G, B} & \text { は } \\
\Delta x_{m}= & {\left[\left(0.344 E_{g}+0.687 E_{b}\right) \alpha_{m}\right.} \\
+ & \left(-0.344 E_{r}+0.083 E_{b}\right) \alpha_{2 m} \\
+ & \left.\left(-0.687 E_{r}-0.083 E_{g}\right) \alpha_{3 m}\right] n_{m} \\
& /\left(0.906 E_{r}+0.827 E_{g}+1.432 E_{b}\right)^{2} \\
\Delta y_{m}= & {\left[\left(-0.285 E_{g}+0.325 E_{b}\right) \alpha_{1 m}\right.} \\
+ & \left(0.285 E_{r}+0.746 E_{b}\right) \alpha_{2 m} \\
+ & \left.\left(-0.325 E_{r}-0.746 E_{g}\right) \alpha_{3 m}\right] n_{m} \\
& /\left(0.906 E_{r}+0.827 E_{g}+1.432 E_{b}\right)^{2}{ }_{m=R, G, B}
\end{aligned}
$$

で与えられ，また(20)式であらわされる新しい色度系に おける色度誤差

$$
\begin{gathered}
\left(\begin{array}{c}
\Delta u_{m} \\
\Delta v_{m}
\end{array}\right)_{m=R, G, B} \text { は } \\
\Delta u_{m}=\frac{m_{1}\left\{\left(1+m_{8} y\right) \Delta x_{m}-m_{8} x \Delta y_{m}\right\}}{\left(m_{7} x+m_{8} y+1\right)^{2}} \\
\Delta v_{m}=\frac{m_{5}\left\{\left(m_{7} x+1\right) \Delta y_{m}-m_{7} y \Delta x_{m}\right\}}{\left(m_{7} x+m_{8} y+1\right)^{2}}
\end{gathered}
$$

で与えられる.

それゆえ, 正弦波ノイズの検知限妨害について考える 之き, 任意の背景色上, (11) 式を満足する $n$ の值を上式 の $n_{m}$ として代入し, さらに(21)式で新しい色度系におけ る色度誤差を求め, これが

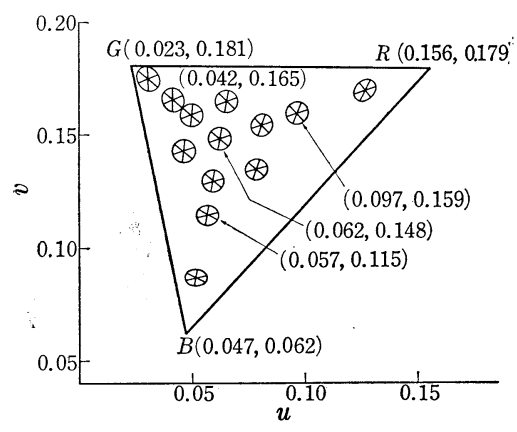

図 4 色度ノイズ用 UCS 色度図 Proposed UCS chromaticity diagram for chrominance noise.

$$
\begin{aligned}
& \Delta u_{m}{ }^{2}+\Delta v_{m}^{2}=k \\
& \text { ただし, } k: \text { 定数 }
\end{aligned}
$$

になるような色度系を求めればよい.

しかし一般に, NTSC 信号の再現色度の全範囲にわた って(22)式を満足するととは困難な問題であり，また， カラーテレビの色再生系を考えるとき, 飽和度の高い領 域では輝度ノイズ成分が増加して，色度ノイズがこれに マスクされるような傾向にあるため，各原色の非飽和領 域において(22)式が正しく満足されるような条件で新し い色度図を導いた。

すなわち, 色度ノイズに対する UCS として新しい表 色系の色度および色度說差は

$$
\begin{aligned}
& u=\frac{0.40 x}{(4.00 y-0.90 x+1.00)} \\
& v=\frac{0.93 y}{(4.00 y-0.90 x+1.00)} \\
& \Delta u=\frac{(0.40+0.90 u) \Delta x-4.00 u \Delta y}{(4.00 y-0.90 x+1.00)} \\
& \Delta v=\frac{0.90 v \Delta x+(0.93-4.00 v) \Delta y}{(4.00 y-0.90 x+1.00)}
\end{aligned}
$$

で与えられる。

図 4 は(11)式であらわされる色度ノイズに刘し(23)式 の UCSN 色度図上に，正弦波色度ノイズによる非検知 範囲を10倍の大きさ(長さの単位で)に拡大して描いたも のである。

なお，乙の色度図では $\mathrm{R}, \mathrm{G}, \mathrm{B}$ 三原色の等エネルギ 一白色点に近いほど色度ノイズの非検知範囲は円形とな り，原色点に近いほどその形状は円形からずれる．との 䛊差は

飽和度が 90\%の画像に対しては約 $3 \mathrm{~dB}$

飽和度が $70 \%$ 以内のものに対しては約 $1.5 \mathrm{~dB}$ 以内

$$
\text { " 50\% } 1.0 \mathrm{~dB} \text { 以内 }
$$

で，色度ノイズが問題となるほとんごの範囲は $1 \mathrm{~dB}$ 以 内の誤差の程度で扱うことができる.

\section{7.一般的な色度ノイズの取り扱いと カラー画像の SN 比 ${ }^{3) 122}$}

\section{1 色信号用三原色信号に混入したノイズによる SN 比}

$E_{r}, E_{g}, E_{b}$ という色信号用 $R, G, B$ 信号に $n_{r}, n_{g}, n_{b}$ で 示されるノイズが混入し，復調信号で，非線形動作をし ている受像管を励振した場合を考える。動作域における 受像管のガンマ $\gamma$ と信号電圧 $E_{r}, E_{g}, E_{b}$ を与えると輝 度ノイズは(6)式より

$$
\begin{aligned}
\Delta Y= & \left(0.299 \alpha_{1 R} E_{r}^{\gamma-1}+0.587 \alpha_{2 R} E_{g}^{\gamma-1}\right. \\
& \left.+0.114 \alpha_{3 R} E_{b}^{\gamma-1}\right) \gamma n_{R}
\end{aligned}
$$




$$
\begin{aligned}
& +\left(0.299 \alpha_{1 G} E_{r}^{\gamma-1}+0.587 \alpha_{2 G} E_{g}^{\gamma-1}\right. \\
& \left.+0.114 \alpha_{3 G} E_{b}^{\gamma-1}\right) \gamma n_{G} \\
& +\left(0.299 \alpha_{1 B} E_{r}^{\gamma-1}+0.587 \alpha_{2 B} E_{g}^{\gamma-1}\right. \\
& \left.+0.114 \alpha_{3 B} E_{b}^{\gamma-1}\right) \gamma n_{B}
\end{aligned}
$$

で与えられ，実効輝度ノイズは

$$
\begin{aligned}
\left(\Delta \bar{Y}^{2}\right)^{1 / 2}= & \gamma\left[\left(0.299 \alpha_{1 R} E_{r}^{\gamma-1}+0.587 \alpha_{2 R} E_{g}{ }^{\gamma-1}\right.\right. \\
& \left.+0.114 \alpha_{3 R} E_{b}{ }^{\gamma-1}\right)^{2} \bar{n}_{R}{ }^{2} \\
& +\left(0.299 \alpha_{1 G} E_{r}^{\gamma-1}+0.587 \alpha_{2 G} E_{g}{ }^{\gamma-1}\right. \\
& \left.+0.114 \alpha_{3 G} E_{b}^{\gamma-1}\right)^{2} \bar{n}_{G}{ }^{2} \\
& +\left(0.299 \alpha_{1 B} E_{r}^{\gamma-1}+0.587 \alpha_{2 B} E_{g}{ }^{\gamma-1}\right. \\
& \left.\left.+0.114 \alpha_{3 B} E_{b}^{\gamma-1}\right)^{2} \bar{n}_{B}{ }^{2}\right]^{1 / 2}
\end{aligned}
$$

となる。

$$
\begin{aligned}
& \text { また色度ノイズは (7)式より } \\
& \Delta x_{R}=\left[\left(0.344 E_{r}^{\gamma}+0.687 E_{b}^{\gamma}\right) E_{r}^{\gamma-1} \alpha_{1 R}\right. \\
& +\left(-0.344 E_{e}^{\gamma}+0.083 E_{b}^{\gamma}\right) E_{g}^{\gamma-1} \alpha_{2 R} \\
& \left.+\left(-0.687 E_{r}^{\gamma}-0.083 E_{g}{ }^{\gamma}\right) E_{b}^{\gamma-1} \alpha_{3 R}\right] \gamma n_{R} / 9 \\
& \Delta y_{R}=\left[\left(-0.285 E_{g}{ }^{\gamma}+0.325 E_{b}{ }^{\gamma}\right) E_{r}{ }^{\gamma-1} \alpha_{1 R}\right. \\
& +\left(0.285 E_{r}^{\gamma}+0.746 E_{b}^{\gamma}\right) E_{q}^{\gamma-1} \alpha_{2 R} \\
& \left.+\left(-0.325 E_{r}^{\gamma}-0.746 E_{g}^{\gamma}\right) E_{b}^{\gamma-1} \alpha_{3 R}\right] \gamma n_{R} / Я
\end{aligned}
$$

$$
\begin{aligned}
\Delta x_{G}= & {\left[\left(0.344 E_{g}^{\gamma}+0.687 E_{b}^{\gamma}\right) E_{r}^{\gamma-1} \alpha_{1 G}\right.} \\
& +\left(-0.344 E_{r}^{\gamma}+0.083 E_{b}^{\gamma}\right) E_{g}^{\gamma-1} \alpha_{2 G} \\
& \left.+\left(-0.687 E_{r}^{\gamma}-0.083 E_{g}^{\gamma}\right) E_{b}^{\gamma-1} \alpha_{3 G}\right] \gamma n_{G} / \text { Я } \\
\Delta y_{G}= & {\left[\left(-0.285 E_{g}^{\gamma}+0.325 E_{b}^{\gamma}\right) E_{r}^{\gamma-1} \alpha_{1 G}\right.} \\
& +\left(0.285 E_{r}^{\gamma}+0.746 E_{b}^{\gamma}\right) E_{g}^{\gamma-1} \alpha_{2 G} \\
& \left.+\left(-0.325 E_{r}^{\gamma}-0.746 E_{g}^{\gamma}\right) E_{b}^{\gamma-1} \alpha_{3 G}\right] \gamma n_{G} / \text { Я }
\end{aligned}
$$

$$
\begin{aligned}
\Delta x_{B}= & {\left[\left(0.344 E_{g}^{\gamma}+0.687 E_{b}^{\gamma}\right) E_{r}^{\gamma-1} \alpha_{1 B}\right.} \\
& +\left(-0.344 E_{r}^{\gamma}+0.083 E_{b}^{\gamma}\right) E_{g}^{\gamma-1} \alpha_{2 B} \\
& \left.+\left(-0.687 E_{r}^{\gamma}-0.083 E_{g}^{\gamma}\right) E_{b}^{\gamma-1} \alpha_{3 B}\right] \gamma n_{B} / Я \\
\Delta y_{B}= & {\left[\left(-0.285 E_{g}^{\gamma}+0.325 E_{b}^{\gamma}\right) E_{r}^{\gamma-1} \alpha_{1 B}\right.} \\
& +\left(0.285 E_{r}^{\gamma}+0.746 E_{b}^{\gamma}\right) E_{g}^{\gamma-1} \alpha_{2 B} \\
& \left.+\left(-0.325 E_{r}^{\gamma}-0.746 E_{g}^{\gamma}\right) E_{b}^{\gamma-1} \alpha_{3 B}\right] \gamma n_{B} / Я
\end{aligned}
$$

ただし，

の 3 組の色度ノイズが共存する。このおのおのに対して 図 4 のUCSN上の色度偏差量 $\Delta n_{c}$ を(23)，(24)式を用い

$$
\begin{aligned}
& \left(\Delta n_{c m}{ }^{2}=\Delta u_{m}^{2}+\Delta v_{m}^{2}\right)_{m=R, G, B} \\
& \Delta n_{c}=\left(\Delta n_{c} R^{2}+\Delta n_{c} G^{2}+\Delta n_{c B^{2}}\right)^{1 / 2}
\end{aligned}
$$

として求め, 信号のノイズ量が与えられているときの色 度ノイズの等価 SN 比を 5.3 の定義にしたがって求める 之,

$$
\left[24-20 \log \left(\frac{\Delta n_{c}}{0.00152}\right)\right] \mathrm{dB}
$$

が $600 \mathrm{kc}$ 帯域の白色ノイズに対する色度ノイズの等価 $\mathrm{SN}$ 比值となる.

\section{色度ノイズの視覚特性とカラーテレビ系への応用】論 文}

\section{2 伝送系の色チャネルに混入したノイズによる SN 比}

カラー信号の伝送途上に扔いて混入したノイズについ ても同様な取り扱いができる。すなおち，搬送色信号内 にその電力密度が $\bar{N}^{2}(f)\left(=\bar{n}^{2}(f) E_{M}{ }^{2}\right)$ のノイズ

$\left(\sqrt{2} n_{i} \cos w_{s} t+\sqrt{2} n_{q} \sin w_{s} t\right) E_{M}$

$$
\text { ただし, } \bar{n}_{i}{ }^{2}=\bar{n}_{q}^{2}=\bar{n}^{2}(f) \Delta f / 2
$$

が加わったとき, 画面上の $R, G, B$ 各光出力は

$$
\begin{aligned}
& E_{r}^{\gamma}+1.14 \gamma E_{r}^{\gamma-1} n_{i} \\
& E_{g}{ }^{\gamma}-0.581 \gamma E_{g}^{\gamma-1} n_{i}-0.394 \gamma E_{g}^{\gamma-1} n_{q} \\
& E_{b}{ }^{\gamma}+2.03 \gamma E_{b}{ }^{\gamma-1} n_{q}
\end{aligned}
$$

に比例したあのとなる. この結果

$$
\begin{aligned}
\left(\Delta \bar{Y}^{2}\right)^{1 / 2}= & {\left[\left\{0.341 \gamma\left(E_{r}^{\gamma-1}-E_{g}{ }^{\gamma-1}\right)\right\}^{2} \bar{n}_{i}{ }^{2}\right.} \\
& \left.+\left\{0.231 \gamma\left(E_{b}^{\gamma-1}-E_{g}^{\gamma-1}\right)\right\}^{2} \bar{n}_{q}{ }^{2}\right]^{1 / 2} \\
= & (\gamma / \sqrt{2})\left[\left\{0.341\left(E_{r}{ }^{\gamma-1}-E_{g}{ }^{\gamma-1}\right)\right\}^{2}\right. \\
& \left.+\left\{0.231\left(E_{b}{ }^{\gamma-1}-E_{g}{ }^{\gamma-1}\right)\right\}^{2}\right]^{1 / 2} \\
& \times\left(\bar{n}^{2}(f) \Delta f\right)^{1 / 2}
\end{aligned}
$$

で示される輝度ノイズが画面にあらわれる.

$$
\begin{aligned}
& \text { また，このときの色度ノイズは } \\
& \Delta x_{i}=\left[1.14\left(0.344 E_{g}^{\gamma}+0.687 E_{b}^{\gamma}\right) E_{r}^{\gamma-1}\right. \\
& \left.-0.581\left(-0.344 E_{r}^{\gamma}+0.083 E_{b}^{\gamma}\right)\right] \gamma \\
& \times\left(\bar{n}^{2}(f) \Delta f\right)^{1 / 2} / \sqrt{2} \text { Я } \\
& \Delta y_{i}=\left\lceil 1.14\left(-0.285 E_{g}^{\gamma}+0.325 E_{b}^{\gamma}\right) E_{r}^{\gamma-1}\right. \\
& \left.-0.581\left(0.285 E_{\tau}^{\gamma}+0.746 E_{b}^{\gamma}\right) E_{g}^{\gamma-1}\right] \gamma \\
& \times\left(\bar{n}^{2}(f) \Delta f\right)^{1 / 2} / \sqrt{2} \text { Я } \\
& \Delta x_{q}=\left[-0.394\left(-0.344 E_{r}^{\gamma}+0.083 E_{b}^{\gamma}\right) E_{g}^{\gamma-1}\right. \\
& \left.+2.03\left(-0.687 E_{r}^{\gamma}-0.083 E_{g}^{\gamma}\right) E_{b}^{\gamma-1}\right] \gamma \\
& \times\left(\bar{n}^{2}(f) \Delta f\right)^{1 / 2} / \sqrt{2} \text { Я } \\
& \Delta y_{q}=\left\lceil-0.394\left(0.285 E_{r}^{\gamma}+0.746 E_{b}^{\gamma}\right) E_{g}^{\gamma-1}\right. \\
& \left.+2.03\left(-0.325 E_{r}^{\gamma}-0.746 E_{g}^{\gamma}\right) E_{b}^{\gamma-1}\right] \gamma \\
& \times\left(\bar{n}^{2}(f) \Delta f\right)^{1 / 2} / \sqrt{2} \text { Я }
\end{aligned}
$$

ただし， Я=(0.906 $\left.E_{r}{ }^{\gamma}+0.827 E_{g}^{\gamma}+1.432 E_{b}^{\gamma}\right)^{2}$ で示される 2 組の色度ノイズが共存する。これらによる $\Delta n_{c}$ の値を 7.1 の場合と同様にして求め, (30)式に代入 すると, 白色ノイズによる色度ノイズの等価 SN 比が計 算できる.

\section{3 カラーテレビ系におけるノイズ量の計算例}

（1）色信号用原色信号の 1 チャネルに混入したノイ ズによる $\mathrm{SN}$ 比

$E_{r}{ }^{1 / \gamma}, E_{g}{ }^{1 / \gamma}, E_{b}{ }^{1 / \gamma}$ であらわされる色信号用三原色信 号の $R$ チャネルに $n_{R}=1 / 35$ の白色ノイズが加わり, 受像 管を $\gamma=2.2$ で動作させたとき, 上記 UCSN 色度を用い て求めた画面ノイズの計算例を表 9 亿示す.

また表10は上記三原色信号に実効値の等しい $n_{R}, n_{G}$ ， $n_{B}$ なる無相関ノイズ 
表 9 色信号用 $R$ 信号の $n_{R}$ による色度, 輝 度ノイズの $\mathrm{SN}$ 比

Tristimulus values of $n_{R}$ on the achromatic color background.

\begin{tabular}{|c|c|c|c|c|c|c|}
\hline \multirow{2}{*}{ 背景 } & \multicolumn{3}{|c|}{ R, G, B 表示 } & \multirow{2}{*}{$\begin{array}{c}\text { 色度ノイ ズの } \\
\text { 等価 SN 比 } \\
(\mathrm{dB})\end{array}$} & \multirow{2}{*}{$\begin{array}{c}\text { ピーク白信号 } \\
\text { に対する輝度 } \\
\text { のSN 比 } \\
\text { (dB) }\end{array}$} & \multirow{2}{*}{$\begin{array}{c}\text { 背景輝度に対す } \\
\text { る輝度 SN 比 } \\
\text { (dB) }\end{array}$} \\
\hline & $\mathrm{R}$ & G & $B$ & & & \\
\hline 白 & 1 & 1 & 1 & 24.0 & $\infty$ & $\infty$ \\
\hline$\uparrow$ & 1 & 0.7 & 0.7 & 22.2 & 52.5 & 50.4 \\
\hline 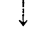 & 1 & 0.5 & 0.5 & 20.8 & 47.6 & 43.9 \\
\hline 赤 & 1 & 0.3 & 0.3 & 19.8 & 44.0 & 38.1 \\
\hline
\end{tabular}

表 10 色信号用三原色信号のノイズによる 色度, 輝度ノイズの SN 比

Chrominance and luminance noise (SNR) due to noise of primary color signal for color channel.

\begin{tabular}{|c|c|c|c|c|c|c|}
\hline \multirow{2}{*}{ 背景 } & \multicolumn{3}{|c|}{$\mathrm{R}, \mathrm{G}, \mathrm{B}$ 表示 } & \multirow{2}{*}{$\begin{array}{c}\text { 色度ノイズの } \\
\text { 等価 SN 此 } \\
\text { (dB) }\end{array}$} & \multirow{2}{*}{ 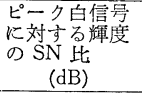 } & \multirow{2}{*}{ 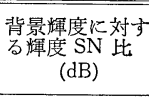 } \\
\hline & $\mathrm{R}$ & G & B & & & \\
\hline 白 & 1 & 1 & 1 & 19. 2 & $\infty$ & $\infty$ \\
\hline & 1 & 0.7 & 0.7 & 17.9 & 50.3 & 48.2 \\
\hline & 1 & 0.5 & 0.5 & 17.1 & 45.3 & 41.5 \\
\hline 赤 & 1 & 0.3 & 0.3 & 16.2 & 41.6 & 35.7 \\
\hline
\end{tabular}

表 11 伝送系での $\mathrm{SN}$ 比 $35 \mathrm{~dB}$ のときの色度, 輝度ノイズ $\mathrm{SN}$ 比

Chrominance and luminance noise (SNR) at $35 \mathrm{~dB}$ SNR of composite color signal.

\begin{tabular}{|c|c|c|c|c|c|c|}
\hline \multirow{2}{*}{ 背景 } & \multicolumn{3}{|c|}{$\mathrm{R}, \mathrm{G}, \mathrm{B}$ 表示 } & \multirow{2}{*}{$\begin{array}{l}\text { 色度ノイズの } \\
\text { 等価 SN 比 } \\
\text { (dB) }\end{array}$} & \multirow{2}{*}{$\begin{array}{c}\text { ピーク白信号 } \\
\text { K対す包輝度 } \\
\text { のSN 此) } \\
\text { (dB) }\end{array}$} & \multirow{2}{*}{$\begin{array}{c}\text { 背景輝度に対す1 } \\
\text { る輝度のSN_比 } 1 \\
\text { (dB) }\end{array}$} \\
\hline & $\mathrm{R}$ & $\mathrm{G}$ & B & & & \\
\hline 白 & 1 & 1 & 1 & 27.8 & $\infty$ & $\infty$ \\
\hline$\hat{\imath}$ & 1 & 0.7 & 0.7 & 26.6 & 60.6 & 58.6 \\
\hline 促 & 1 & 0.5 & 0.5 & 25.8 & 55.7 & 52.0 \\
\hline 赤 & 1 & 0.3 & 0.3 & 25.2 & 52.1 & 46.2 \\
\hline
\end{tabular}

$$
\left(\bar{n}_{R}\right)^{1 / 2}=\left(\bar{n}_{G}{ }^{2}\right)^{1 / 2}=\left(\bar{n}_{B}{ }^{2}\right)^{1 / 2}=1 / 35
$$

が加わったときの計算例である.

（2）伝送系の色チャネルに混入したノイズによる $\mathrm{SN}$ 比

帯域 $f_{\omega}=4.0 \mathrm{Mc}$ で定義した信号の SN 比が $35 \mathrm{~dB}$ に なるような白色ノイズが加わった場合，色チャネルから 画面にあらわれるノイズを 7.2 にあげた諸式を用いて計 算すると，表 11 のようになる。

表 11 は白色から飽和した赤色へ之背景色が変わって 行った場合の色度ノイズの等洒 $\mathrm{SN}$ 比㧍よび輝度ノイズ $\mathrm{SN}$ 比の計算例を示したもので，てのような背景色上で は $n_{q}$ による輝度ノイズは常に 0 となり, 輝度ノイズは $n_{i}$ 成分によってのみあらわれる.との表を見ると $4.0 \mathrm{Mc}$ 帯域で定義した信号の SN 比が $35 \mathrm{~dB}$ の白色ノイズに対 する色度ノイズは検知されないととがわかる。

これは，標準カラーバー信号に正弦 2 乗フィルターで 帯域制限した白色ノイズを加え，てれをカラーモニター 上にディスプレーして確かめた。

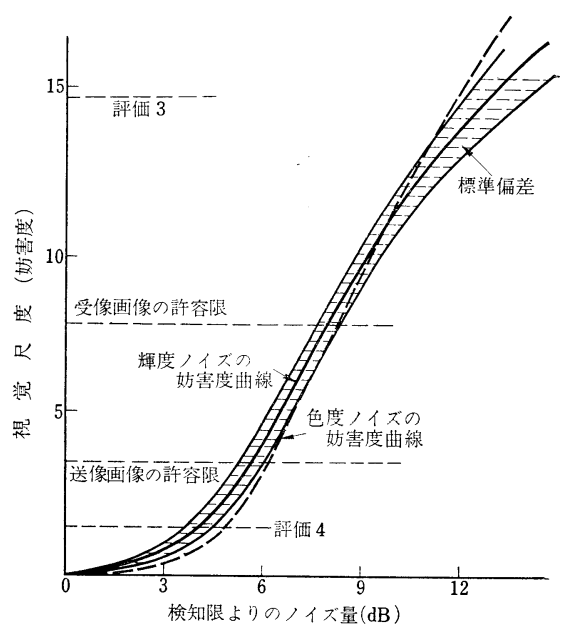

(a)

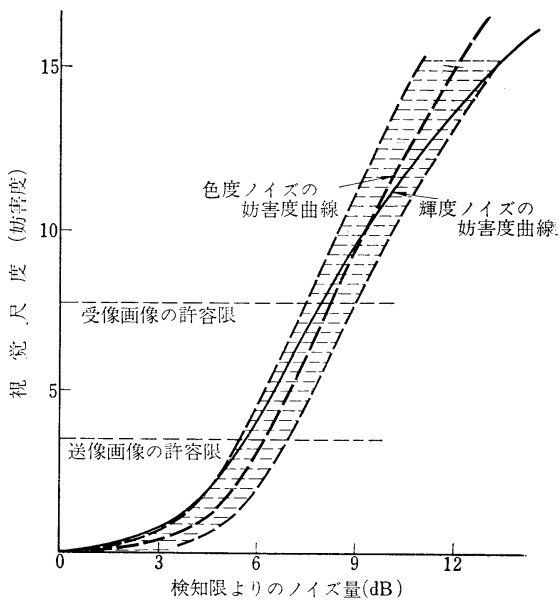

(b)

図 5 輝度ノイズ妨害と色度ノイズ妨害 Subjective scale of luminance and chrominance noise disturbance.

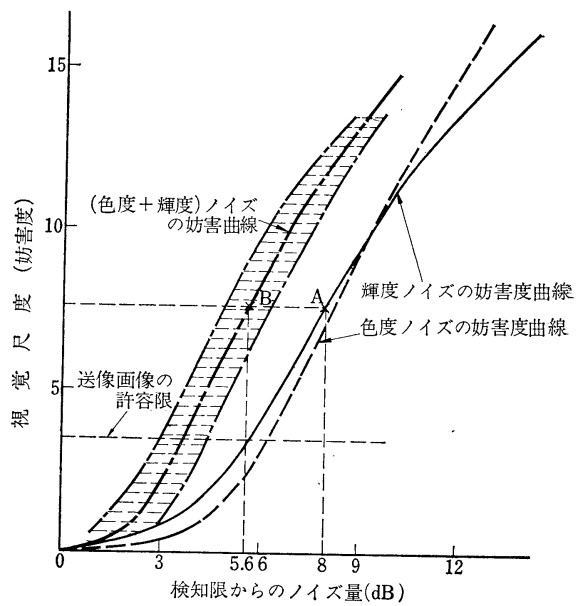

図 6 輝度と色度ノイズが共存したときの妨害度 Subjective scale of color noise disturbance. (includes luminance noise and chrominance noise) 


\section{4 色度ノイズ妨害と輝度ノイズ妨害 ${ }^{3) 12}$}

図 5(a) (b) は横軸に検知限から測ったノイズ量を, 縱軸に妨害尺度をとり JND法 (Just Noticeable Difference Method) によって求めた輝度ノイズと色度ノイズの妨害 度曲線である.太線はこの平均值, 斜線は標準偏差を示 す.

また，図 6 は輝度ノイズと色度ノイズとが抢の抢の検 知限加測って等しい量ずつ共存するとき，その妨害度 がどれくらい増加するかを示したすので，たとえば，図 の $\mathrm{A} ， \mathrm{~B}$ 点上り検知限加引測っておのおの $5.6 \mathrm{~dB}$ の色 度ノイズと輝度ノイズが共存したときの妨害は，輝度ノ イズ単独で $8 \mathrm{~dB}$ の妨害に対応することを示している.

この結果，特にノイズ量が小さいときには，色度ノイ ズ量と輝度ノイズ量を電力的に加え合わせるような方法 で取り扱えないことを示している。

\section{8.むす び}

色度ノイズは，乙れを色紙などによっては表現しにく いという性質上，従来その取り扱い法が不明確であった が，カラー受像管を使用すれば色度ノイズのみのディス プレーが容易であり，乙れを用いてカラーテレビ系のノ イズを検討した。

まず，カラーテレビの色度ノイズについて解析し，そ の結果, 色度ノイズ量を 3 つの色差チャネルのノイズを 形成するあとのノイズ量で定義する方法をとり，乙の段 階で互いに無相関な色度ノイズを電力的に加算して取り 扱えるようにした．このようにして取り扱った色度ノイ ズを，カラー受像管上いろいろな背景色の上にディスプ レーし，評佂試験を行なって，色度ノイズの視覚特性を 検討した. この結果，色度ノイズの妨害量が背景色を構 成する三原色刺戟量に重み係数をもたせた背景色の関数 であらわしうるととを見出し，その表示式を導いた。

さらにとれを広く，カラーテレビの非線形動作のもの に対しても適用することができるよう, 色度ノイズに対 するUCS 色度図 (UCSN) 導き, 色度ノイズ量を数式 的に取り扱えるようにした，乙の新しい色度図を用いる と, $70 \%$ 飽和度までの背景色に対しては $1.5 \mathrm{~dB}$ 以内の 誤差で色度ノイズを数式的に取り扱うことができる．ま た応用例として，乙の UCSN を用い，カラーカメラの
ノイズによる画面ノイズ，伝送系で混入したノイズによ る画面ノイズを計算し，そのうちのいくつかは視覚試験 して色度ノイズの計算に適用しうることを確かめた。

本検討注刘象にした背景が画像内容をむたないりリッ ドラスターとしたため, 大面積にわたって同一の色彩画 像のノイズにしか対応しないという点や，観視場所が暗 室で面面輝度が十数fL以下の画面之いう限ら机た条件 のもとに打けるものではあるが，一応色度ノイズを数式 的に取り扱えるようになった。

以上，色度ノイズに関し二，三検討を行なってきたが これに対する評価試験は, 斎藤(秀)職員の研修研究項目 として共同で行なったあので，斎藤職員の協力によると ころが大きい。

最後に，いろいろご指導之助言をいただいた寺山テレ ビ研究部長, 桶渡, 林, 佐藤(俊), 渡部主任研究員なら びに試験回路調整にで助力を得た杉浦職員，評洒法とそ の処理法についてご指導下さった森職員, 評価にご協力 いただいた方式研究室, 無線研究部受信機研究室の方々 に謝意を表す。

(昭和 41 年 7 月 20 日受付)

\section{〔参 考 文 献〕}

1) W. F. Bailey: The Constant Luminance Principle in NTSC Color Television, IRE, 42,14

2）藤尾：色チャンネルからの雑音，所内カラーカメラ研究委資料 (40年 3 月)

3）藤尾：カラーテレビ系に批ける色度ノイズの取扱法，技研例報 40, 24 藤尾：色度ノイズの視覚特性とカラーテレビ系に㧍ける取扱法 （其の 2 )，研報，3110

4) 藤尾, 竟藤：色度ノイズの視党特性とカラーテレビ系への応用, テレビ学会画質委資料 (40年 7 月) 藤尾，斎藤：色度ノイズの視覚特性とカラーテレビ系に括ける 色度ノイズ取扱法（其の 1 )，研報，3111

5）藤尾：色度ノイズの視覚特性とその取扱い方について，テレヒ 学会色彩委資料 (40年11月)

6) 林：カラーテレピのノイズ, テレビ誌, 17, 1 (1963)

7) 樋渡：テレビジョンノイズ主観評価，テレビ誌，17，1 (1963)

8) 駒井, 小林: カラーテレビ信号の雑音の再現色に及ぼす影響に ついて, TV 談話会, 第 3 号

9) 藤尾，林，斎藤：色度ノイズの視覚評価，第 1 回テレビ学会全 大学, 1-7

10) D. B. Judd: Color in Business, Science and Industry, John Wiley \& Sons Inc.

11) D. L. MacAdam: Projective Transformation of ICI Color Specification, JOSA, Aug. (1937)

12）藤尾：カラーテレビ系に拊る色度ノイズの影響，昭 41 年電笑 四学会連大予, 144

13）放送技術双書：カラーテレビジョン，NHK 出版協会

14）官能検查ハンドブック：日科技連, JUSE 出版社 